Supporting information

\title{
Boosting the Long-Term Stability of Hydrotalcite-Derived Catalysts in Hydrogenolysis of Glycerol by Incorporation of $\mathrm{Ca}(\mathrm{II})$
}

Honghui Gong, ${ }^{\dagger}$ Xiuge Zhao,${ }^{\dagger}$ Xiyu $\mathrm{Li},{ }^{\dagger}$ Manyu Chen,${ }^{\dagger}$ Yuan Ma,${ }^{\dagger}$ Jian Fang,${ }^{\dagger}$ Xinjia Wei, ${ }^{\dagger}$ Qingpo Peng, ${ }^{\dagger}$ and Zhenshan $\mathrm{Hou}^{*, \dagger}$

${ }^{\dagger}$ Key Laboratory for Advanced Materials, Research Institute of Industrial Catalysis, School of Chemistry \& Molecular Engineering, East China University of Science and Technology, 130 Meilong Road, Xuhui District, Shanghai 200237, China.

Corresponding author: E-mail: houzhenshan@ecust.edu.cn

Number of Pages: 22

Number of Figures: 11

Number of Tables: 3 
Table of contents

Experiment

Section

\section{S8}

Figure $\mathrm{S} 1 \quad \mathrm{XRD}$ patterns of $\mathrm{HT}$ precursors and $\mathrm{CaCO}_{3} \ldots \ldots \ldots \ldots \ldots \ldots . \mathrm{S} 9$

Figure S2 $\quad$ FT-IR spectra of the samples.......................... S10

Figure S3 SEM images of the catalysts........................... S11

Figure S4 Influence of various reaction parameters on the catalytic performance............................................ S12

Figure S5 The recyclability of $\mathrm{Co}_{6}-\mathrm{Al}_{3}$ catalyst..................... S13

Figure S6 XRD patterns of the spent catalysts..................... S14

Figure S7 SEM images of the spent catalysts....................... S15

Figure S8 TGA curves of catalysts.............................. S16

Table S2 Comparison of the $\mathrm{Co}_{2}-\mathrm{Ca}_{4}-\mathrm{Al}_{3}$ catalyst with reported catalytic systems............................................. S17

Figure $\mathrm{S} 9$ (a) XRD patterns of the $\mathrm{Co}_{2}-\mathrm{Ca}_{4}-\mathrm{Al}_{3} \mathrm{OH}_{-} \mathrm{HT}$ and $\mathrm{Co}_{2}-\mathrm{Ca}_{4}-$ $\mathrm{Al}_{3}$ OH. (b) $\mathrm{H}_{2}-\mathrm{TPR}$ profiles of the $\mathrm{Co}_{2}-\mathrm{Ca}_{4}-\mathrm{Al}_{3} \_\mathrm{OH} \_\mathrm{HT}$. (c)

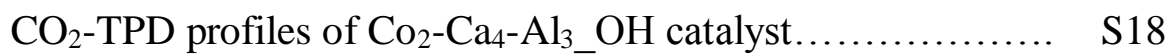

Table S3 The hydrogenolysis of glycerol on various catalysts........... S19

Figure S10 The recyclability of $\mathrm{Co}_{2}-\mathrm{Ca}_{4}-\mathrm{Al}_{3} \_\mathrm{OH}$ catalyst................ S20

Figure $\mathrm{S} 11$ (a) XRD patterns of the $\mathrm{Co}_{2}-\mathrm{Ca}_{4}-\mathrm{Al}_{3}$ Ox catalysts; (b) Co $2 \mathrm{p}$ XPS spectrum of the $\mathrm{Co}_{2}-\mathrm{Ca}_{4}-\mathrm{Al}_{3} \_\mathrm{Ox}$ catalyst.............. S21

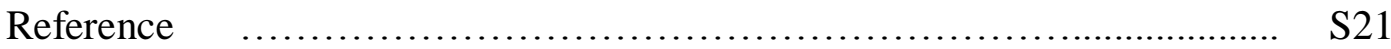




\section{Experimental Section}

\section{Materials}

All the materials and reagents were commercially available and were not purified further prior to use. Cobalt nitrate hexahydrate $\left(\mathrm{Co}\left(\mathrm{NO}_{3}\right)_{2} \cdot 6 \mathrm{H}_{2} \mathrm{O}, 99 \%\right)$ was supplied by Macklin Biochemical Co., Ltd. Sodium hydroxide $(\mathrm{NaOH}, 97 \%)$, and sodium carbonate anhydrous $\left(\mathrm{Na}_{2} \mathrm{CO}_{3}, 99 \%\right)$ were bought from Aladdin Industrial Corporation. Calcium nitrate tetrahydrate $\left(\mathrm{Ca}\left(\mathrm{NO}_{3}\right)_{2} \cdot 4 \mathrm{H}_{2} \mathrm{O}, 99 \%\right)$, aluminium nitrate $\left(\mathrm{Al}\left(\mathrm{NO}_{3}\right)_{3} \cdot 9 \mathrm{H}_{2} \mathrm{O}, 99 \%\right)$ were provided by Shanghai Lingfeng Chemical Reagent Co., Ltd. High purity $\mathrm{N}_{2}(99.999 \%)$ and $\mathrm{H}_{2}(99.999 \%)$ was supplied by Shanghai Pujiang Specialty Gases Co., Ltd. Crude glycerol was directly purchased from Hebei Fucheng Chemical Co., Ltd without any further purification. The composition of crude glycerol aqueous solution utilized in this study was shown in Table S1. It can be seen that the crude glycerol used in this study has $50.2 \mathrm{wt} \%$ glycerol content and is accompanied by water (47.3 wt \%), MONG (1.45 wt \%) as main impurities, as well as high content of sodium (559 ppm) probably due to the catalyst $(\mathrm{NaOH})$ employed in biodiesel production. All other chemicals were bought from Sino pharm Chemical and used without further purification.

\section{Catalysts Preparation}

The Co-Ca-Al_HT with different molar ratios of Co:Ca:Al were prepared by concurrent-precipitation method according to the following procedure. In a typical example, the required amounts of $\mathrm{M}^{2+}\left(\mathrm{Co}\left(\mathrm{NO}_{3}\right)_{2} \cdot 6 \mathrm{H}_{2} \mathrm{O}\right.$ and/or $\mathrm{Ca}\left(\mathrm{NO}_{3}\right)_{2} \cdot 4 \mathrm{H}_{2} \mathrm{O}, 0.06$ mol) and $\mathrm{M}^{3+}\left(\mathrm{Al}\left(\mathrm{NO}_{3}\right)_{3} \cdot 9 \mathrm{H}_{2} \mathrm{O}, 0.03 \mathrm{~mol}\right)$ were dissolved in $120 \mathrm{~mL}$ distilled water under stirring, and this solution was referred as $\mathrm{A}$, in which $\mathrm{M}^{2+} / \mathrm{M}^{3+}=2$ and the total molar amount of metal ions (including $\mathrm{M}^{2+}$ and $\mathrm{M}^{3+}$ ) is 0.09 mol. Solution B containing $\mathrm{NaOH}(0.21 \mathrm{~mol})$ and $\mathrm{Na}_{2} \mathrm{CO}_{3}(0.089 \mathrm{~mol})$ was dissolved in $120 \mathrm{~mL}$ distilled water. Then solution A and B were added slowly to a $500 \mathrm{~mL}$ three-necked flask under vigorously stirring at room temperature, the $\mathrm{pH}$ was maintained at 10 during dripping process. The resulted suspension processed at $75^{\circ} \mathrm{C}$ for $1 \mathrm{~h}$ and then stopped stirring 
and aging at this temperature for 18 hours. After aging, the precipitate was filtered, followed by washing thoroughly with distilled water until the $\mathrm{pH}$ of filtrate reached 7.0. The obtained precipitate was then dried at $80^{\circ} \mathrm{C}$ for $12 \mathrm{~h}$ to obtain pink powder and designated as $\mathrm{Co}_{6-\mathrm{x}}-\mathrm{Ca}_{\mathrm{x}}-\mathrm{Al}_{3}$ HT, where $\mathrm{x}$ referred to the molar ratios of $\mathrm{Ca}(\mathrm{II})$ and was equal to $0-5$, respectively. The resulting material was calcined in a reduction atmosphere $\left(\mathrm{H}_{2} / \mathrm{N}_{2}=1 / 9, \mathrm{v} / \mathrm{v}\right)$ at $600^{\circ} \mathrm{C}$ (heating rate: $\left.5^{\circ} \mathrm{C} \cdot \mathrm{min}^{-1}\right)$ for $2 \mathrm{~h}$. After the catalyst was cooled to room temperature, it was then passivated by mixed gas $\left(\mathrm{O}_{2}: \mathrm{N}_{2}=1: 99\right.$, v/v) for $2 \mathrm{~h}$ to achieve the corresponding catalysts, which were named as $\mathrm{Co}_{6-\mathrm{x}}-\mathrm{Ca}_{\mathrm{x}}-\mathrm{Al}_{3}$. For the sake of comparison, $\mathrm{Co}_{2}-\mathrm{Ca}_{4}-\mathrm{Al}_{3} \mathrm{O}_{2} \mathrm{Ox}$ was prepared by re-oxidation of $\mathrm{Co}_{2}-\mathrm{Ca}_{4}-\mathrm{Al}_{3}$ at $300^{\circ} \mathrm{C}$ for $2 \mathrm{~h}$ in air.

To investigate the effect of interlayer anions of $\mathrm{CO}_{3}{ }^{2-}$, the $\mathrm{Co}_{2}-\mathrm{Ca}_{4}-\mathrm{Al}_{3} \mathrm{OH}_{-} \mathrm{HT}$ was also prepared by the same method as $\mathrm{Co}_{2}-\mathrm{Ca}_{4}-\mathrm{Al}_{3} \mathrm{HT}$, except that there was no $\mathrm{Na}_{2} \mathrm{CO}_{3}$ in solution $\mathrm{B}$ and the material was synthesized in a flow of $\mathrm{N}_{2}$. The resulting catalyst was named as $\mathrm{Co}_{2}-\mathrm{Ca}_{4}-\mathrm{Al}_{3} \mathrm{OH}$ after the $\mathrm{Co}_{2}-\mathrm{Ca}_{4}-\mathrm{Al}_{3} \mathrm{OH}_{-} \mathrm{HT}$ was calcined under a reduction atmosphere $\left(\mathrm{H}_{2} / \mathrm{N}_{2}=1 / 9, \mathrm{v} / \mathrm{v}\right)$ at $600^{\circ} \mathrm{C}$. Besides, $\mathrm{CaCO}_{3}$ was also prepared by concurrent-precipitation method. $50 \mathrm{~mL}$ of aqueous solution containing $1.78 \mathrm{M} \mathrm{Na}_{2} \mathrm{CO}_{3}$ was added slowly to $50 \mathrm{~mL}$ aqueous solution containing $0.4 \mathrm{M} \mathrm{Ca}\left(\mathrm{NO}_{3}\right)_{2} \cdot 4 \mathrm{H}_{2} \mathrm{O}$ under vigorously stirring at room temperature, the $\mathrm{pH}$ was maintained at 10 during dripping process. The resulted suspension processed at $75^{\circ} \mathrm{C}$ for $1 \mathrm{~h}$ and then stopped stirring and aging at this temperature for 18 hours. The resulted suspension was filtered, followed by washing thoroughly with distilled water until the $\mathrm{pH}$ of filtrate reached 7.0. The obtained precipitate was then dried at $80^{\circ} \mathrm{C}$ for $12 \mathrm{~h}$ and calcined at $600^{\circ} \mathrm{C}$ (heating rate: $5^{\circ} \mathrm{C} \cdot \mathrm{min}^{-1}$ ) for $2 \mathrm{~h}$ to obtain white powder and designated as $\mathrm{CaCO}_{3}$.

\section{Catalyst Characterization}

X-ray diffraction (XRD) analysis of the samples were performed in the $2 \theta$ range of $5^{\circ}-75^{\circ}$ on an Rigaku D/MAX $2550 \mathrm{VB} / \mathrm{PC}$ instrument using $\mathrm{Cu} \mathrm{K} \alpha$ radiation. The textural properties from $\mathrm{N}_{2}$ adsorption isotherms were obtained on Quanta chrome NOVA 2200e equipment. BET surface area and pore structure were calculated on adsorption branch. The inductively coupled plasmaatomic emission spectroscopy (ICP- 
AES) analysis was carried out on a Varian ICP-710ES instrument. The sample was putted in a plastic beaker mixed with a certain amount of aqua regia at $80^{\circ} \mathrm{C}$ for $2 \mathrm{~h}$, followed by diluted with water. Temperature-programmed reduction $\left(\mathrm{H}_{2}-\mathrm{TPR}\right)$ was performed using VDsorb-91i. The catalyst was placed in a U-shaped quartz tube, then purged under pure $\operatorname{Ar}\left(10 \mathrm{~mL} \cdot \mathrm{min}^{-1}\right)$ flow at $400^{\circ} \mathrm{C}$ for $2 \mathrm{~h}$, and then cooled down to $20^{\circ} \mathrm{C}$. After that, it was reduced with $\mathrm{H}_{2} / \mathrm{Ar}(1 / 9, \mathrm{v} / \mathrm{v})\left(10 \mathrm{~mL} \cdot \mathrm{min}^{-1}\right)$ up to $900^{\circ} \mathrm{C}(\mathrm{ramp}$ rate of $\left.10^{\circ} \mathrm{C} \cdot \mathrm{min}^{-1}\right)$. A cooling trap was employed to condense the minor water vapor before the carrier gas flowed into the TCD detector in $\mathrm{H}_{2}$-TPR analyses. The thermal stability of catalysts was determined by Thermogravimetry analysis (TGA) method (heating rate: $10^{\circ} \mathrm{C} \cdot \mathrm{min}^{-1}$; air flow, $100 \mathrm{~mL} \cdot \mathrm{min}^{-1}$ ) using PerkinElmerPyris Diamond Analyser. The Scanning electron microscopy (SEM) images were performed on GeminiSEM 500. High resolution transmission electron microscopy (HRTEM) was performed in a JEOL JEM 2010 transmission electron microscope operating at $200 \mathrm{kV}$ with a nominal resolution of $0.25 \mathrm{~nm}$. The samples for HRTEM were prepared by dropping the aqueous solutions containing the catalysts onto the carbon-coated $\mathrm{Cu}$ grids. Energy dispersive X-ray spectroscopy (EDS) was carried out using 4 in-column SuperX detectors. X-ray photoelectron spectroscopy (XPS) was performed using Thermo ESCALAB 250. The basicity of Co-based catalysts was carried out via temperatureprogrammed desorption of $\mathrm{CO}_{2}\left(\mathrm{CO}_{2}-\mathrm{TPD}\right)$. Samples were first pretreatment at $300^{\circ} \mathrm{C}$ in purified $\mathrm{Ar}$ flow of $30 \mathrm{~mL} \cdot \mathrm{min}^{-1}$ for $1 \mathrm{~h}$, and then cooled to $100^{\circ} \mathrm{C}$, exposed to $50 \%$ $\mathrm{CO}_{2} / \mathrm{Ar}$ for $30 \mathrm{~min}$, purged by $\mathrm{Ar}$ for $5 \mathrm{~h}$ at $100^{\circ} \mathrm{C}$ in order to eliminate the physical adsorbed $\mathrm{CO}_{2}$. Temperature-programmed desorption (TPD) was conducted by ramping to $800^{\circ} \mathrm{C}$ (heating rate: $\left.10^{\circ} \mathrm{C} \cdot \mathrm{min}^{-1}\right)$ and $\mathrm{CO}_{2}(\mathrm{~m} / \mathrm{e}=44)$ in effluent was detected and recorded as a function of temperature by a quadrupole mass spectrometer (OmniStarTM, GSD301, Switzerland).

The adsorption states of glycerol on catalysts were studied on a Nicolet Magna 550 FT-IR spectrometer. The spectrum of sample without absorbed glycerol was recorded as background. The FT-IR spectra of the Co-based catalysts after introducing glycerol $\left(2.0 \mathrm{mmol} \mathrm{g}^{-1}\right)$ were carried out according to the following procedure: a mixture of glycerol $(0.2 \mathrm{mmol}), \mathrm{H}_{2} \mathrm{O}(2.0 \mathrm{~mL})$ and the catalysts $(0.1 \mathrm{~g})$ were placed in 
a $25.0 \mathrm{~mL}$ Schlenk flask and stirred for $1 \mathrm{~h}$, followed by drying under the vacuum for $2 \mathrm{~h}$ at $70^{\circ} \mathrm{C}$. The resulting sample was subjected to FT-IR measurement.

\section{Catalytic Reactions}

In a batch-wise reaction, a $50 \mathrm{~mL}$ stainless steel autoclave was used and equipped with a thermoelectric couple. Aqueous solution of substrates $(15.0 \mathrm{~mL}, 20 \mathrm{wt} \%$ for glycerol and other sugar alcohols but $5 \mathrm{wt} \%$ for glucose unless otherwise indicated) and $0.5 \mathrm{~g}$ catalysts were added to the reactor. The reactor was purged three times with $\mathrm{N}_{2}$ to replace the air in the autoclave, and then three times with pure $\mathrm{H}_{2}$ to replace the $\mathrm{N}_{2}$. Finally, hydrogen was added to the given pressure and the reactor was heated to the given temperature under vigorously stirring. When the hydrogenation reaction was carried out under low pressure $(<2.0 \mathrm{MPa})$, hydrogen was supplied continuously to the autoclave through a single-way valve during the reaction. After the reaction was finished, the reactor was quenched in an ice-water bath to stop the reaction and then the catalyst was filtrated to separate from the solution before analysis. The liquid products were qualitatively analyzed by an Agilent 6890/5973 GC-MS system equipped with a HP-5MS column (30 m long, $0.25 \mathrm{~mm}$ i.d., $0.25 \mu \mathrm{m}$ film thickness) and flame ionization detector (FID). For quantitative measurements, analysis was performed on a GC128 gas chromatograph equipped with an FFAP capillary column (30 m long, 0.32 mm i.d., $0.33 \mu \mathrm{m}$ film thickness) and 1-butanol was used as the internal standard. High performance liquid chromatography (HPLC) equipped with a refractive index detector in series with SilGreen H column $(300 \mathrm{~mm} \times 7.8 \mathrm{~mm})$ together with a guard cartridge was also employed for product analysis (e.g. LA). The column oven temperature was $50^{\circ} \mathrm{C}$, the mobile phase was diluted with a concentration of $5 \mathrm{mM} \mathrm{H}_{2} \mathrm{SO}_{4}$ aqueous solution and $0.5 \mathrm{~mL} \cdot \mathrm{min}^{-1}$ flow rate, $20 \mu \mathrm{L}$ of each sample was injected and peaks were detected with refractive index detector. The gaseous products were collected and analyzed by offline GC with thermal conductivity detector (TCD). To examine the recyclability of the optimized catalyst, the catalyst was separated from the reaction mixture by filtration, following by washing three times with distilled water and three times with $\mathrm{EtOH}$, respectively. Finally, the resulting material was then dried at $80^{\circ} \mathrm{C}$ for 
$3 \mathrm{~h}$, which was added to a fresh reaction solution for the next run.

To further evaluate the long-term stability of the catalyst, the hydrogenolysis of glycerol was also carried out in a vertical fixed-bed stainless-steel reactor $(1.1 \mathrm{~cm}$ i.d., length $60 \mathrm{~cm}$ ). The solid catalyst was tableted and then crushed and sieved to 20-40 mesh particles for the catalytic reaction tests. A constant weight ( $2.0 \mathrm{~g})$ of catalyst layer was sandwiched in the middle of the reactor with quartz wool and quartz sand for supporting the catalyst and evaporation of the reactants. The temperature was controlled by a thermocouple placed in the middle of the catalyst bed. When the temperature of reactor was constant, the feedstock, an aqueous solution containing $20 \mathrm{wt} \%$ glycerol, was then pumped into the reactor $\left(0.04 \mathrm{~mL} \cdot \mathrm{min}^{-1}\right)$ and driven through the catalyst bed by hydrogen flow $\left(15 \mathrm{~mL} \cdot \mathrm{min}^{-1}\right)$. The reaction products were condensed in a cryogenic cooling system and collected every $10 \mathrm{~h}$ for offline analysis. For quantitative measurements, 1-butanol was used as the internal standard. The gaseous products were also collected and analyzed by offline GC with thermal conductivity detector (TCD). The conversion of substrate was calculated using equation S1.

Conversion $(\%)$

$$
=\frac{\text { amount of substrate reacted (mole) }}{\text { total amount of substrate used in the reaction }(\text { mole })} \times 100 \%
$$

Product selectivity and yield were calculated using equations S2 and S3.

$$
\begin{aligned}
& \text { Selectivity }(\%)=\frac{\text { carbon in a productdefined }(\text { mole })}{\text { carbon in substratereacted }(\text { mole })} \times 100 \% \\
& \text { Yield }(\%)=\frac{\text { Conversion }(\%) \times \text { Selectivity }(\%)}{100}
\end{aligned}
$$


Table S1. The composition of crude glycerol (brown color) utilized in this study.

\begin{tabular}{ccc}
\hline Parameter & Unit & Content \\
\hline Glycerol content & $\% \mathrm{w} / \mathrm{w}$ & $50.20 \%$ \\
MONG & $\% \mathrm{w} / \mathrm{w}$ & $1.45 \%$ \\
Ash Content $\left(550^{\circ} \mathrm{C}\right)$ & $\% \mathrm{w} / \mathrm{w}$ & $0.68 \%$ \\
Water content & $\% \mathrm{w} / \mathrm{w}$ & $47.30 \%$ \\
$\mathrm{pH}$ at $25^{\circ} \mathrm{C}$ & - & 6.8 \\
Sodium content & $\mathrm{ppm}$ & 559 \\
\hline
\end{tabular}




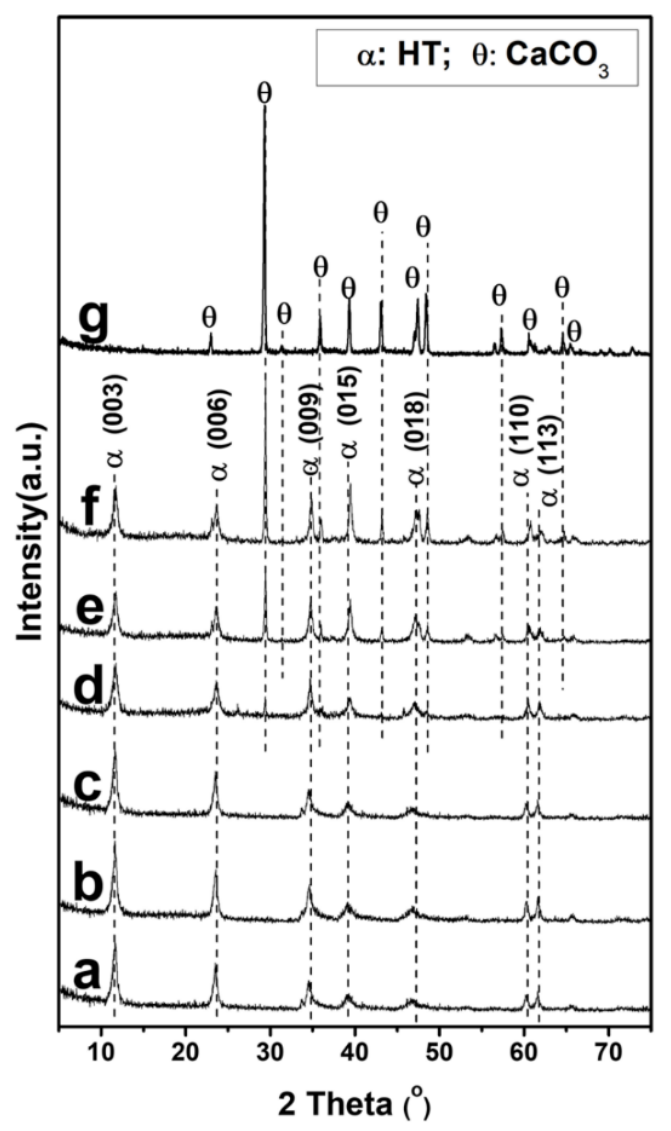

Figure S1. XRD patterns of (a) $\mathrm{Co}_{6}-\mathrm{Al}_{3} \_\mathrm{HT}$; (b) $\mathrm{Co}_{5}-\mathrm{Ca}_{1}-\mathrm{Al}_{3} \mathrm{HT}$; (c) $\mathrm{Co}_{4}-\mathrm{Ca}_{2}-\mathrm{Al}_{3}$ HT; (d) $\mathrm{Co}_{3}-\mathrm{Ca}_{3}-\mathrm{Al}_{3} \_\mathrm{HT}$; (e) $\mathrm{Co}_{2}-\mathrm{Ca}_{4}-\mathrm{Al}_{3} \mathrm{HT}_{2}$; (f) $\mathrm{Co}_{1}-\mathrm{Ca}_{5}-\mathrm{Al}_{3} \_\mathrm{HT}$; (g) $\mathrm{CaCO}_{3}$. 


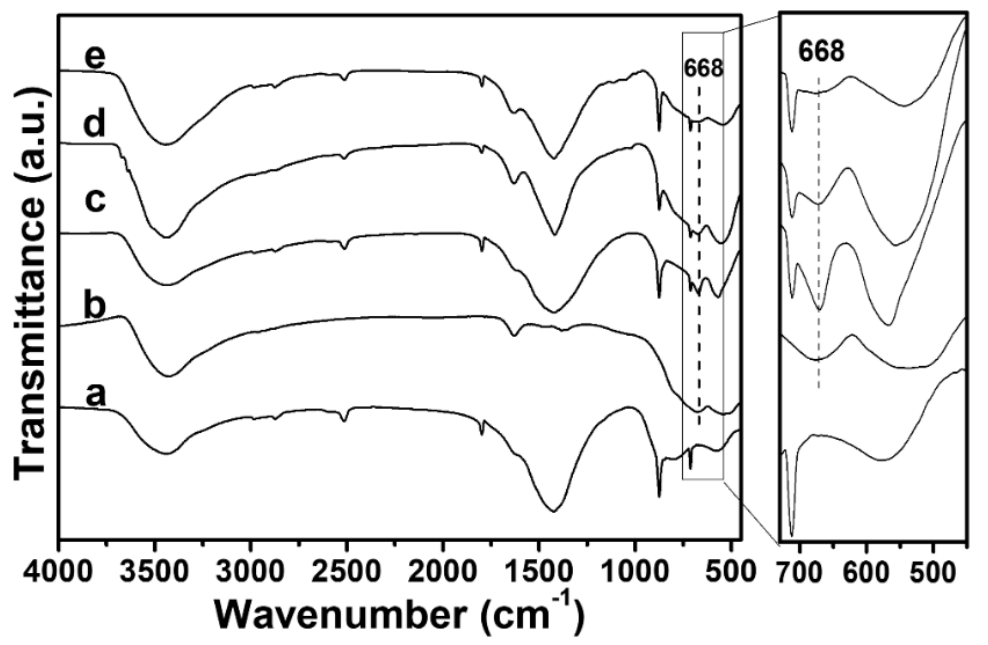

Figure S2. FT-IR spectra of the samples. (a) $\mathrm{CaCO}_{3}$; (b) $\mathrm{Co}_{6}-\mathrm{Al}_{3}$; (c) $\mathrm{Co}_{3}-\mathrm{Ca}_{3}-\mathrm{Al}_{3}$; (d) $\mathrm{Co}_{2}-\mathrm{Ca}_{4}-\mathrm{Al}_{3}$; (e) $\mathrm{Co}_{1}-\mathrm{Ca}_{5}-\mathrm{Al}_{3}$. 


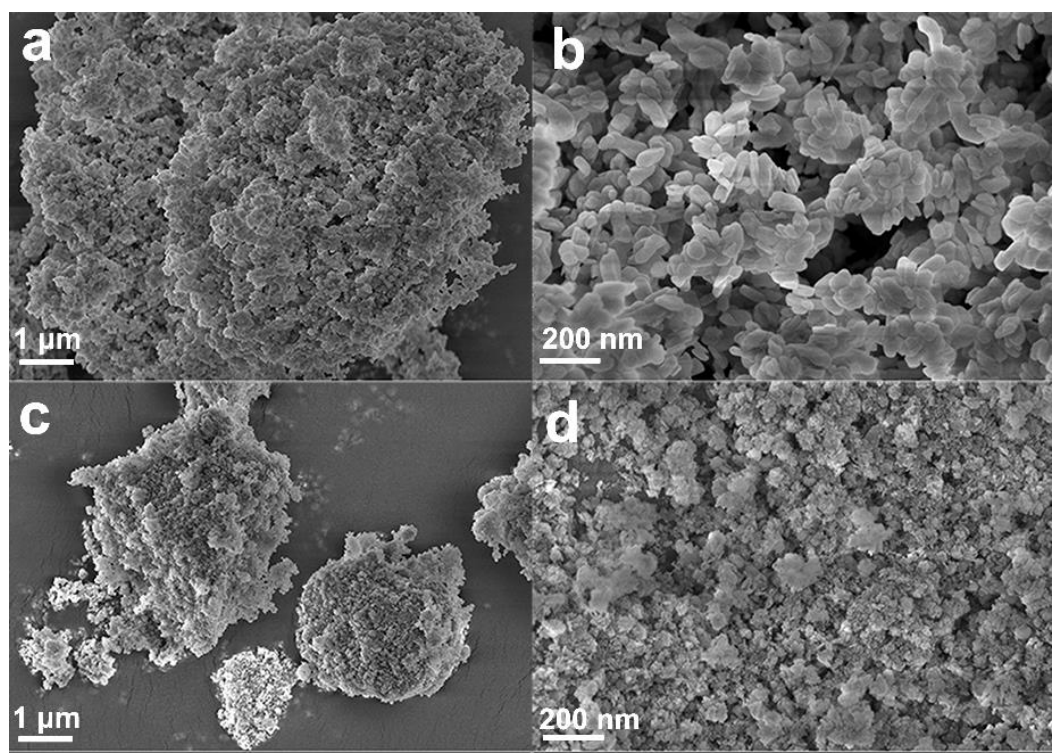

Figure S3. SEM images of the catalysts. (a, b) $\mathrm{Co}_{6}-\mathrm{Al}_{3}$; (c, d) $\mathrm{Co}_{2}-\mathrm{Ca}_{4}-\mathrm{Al}_{3}$. 

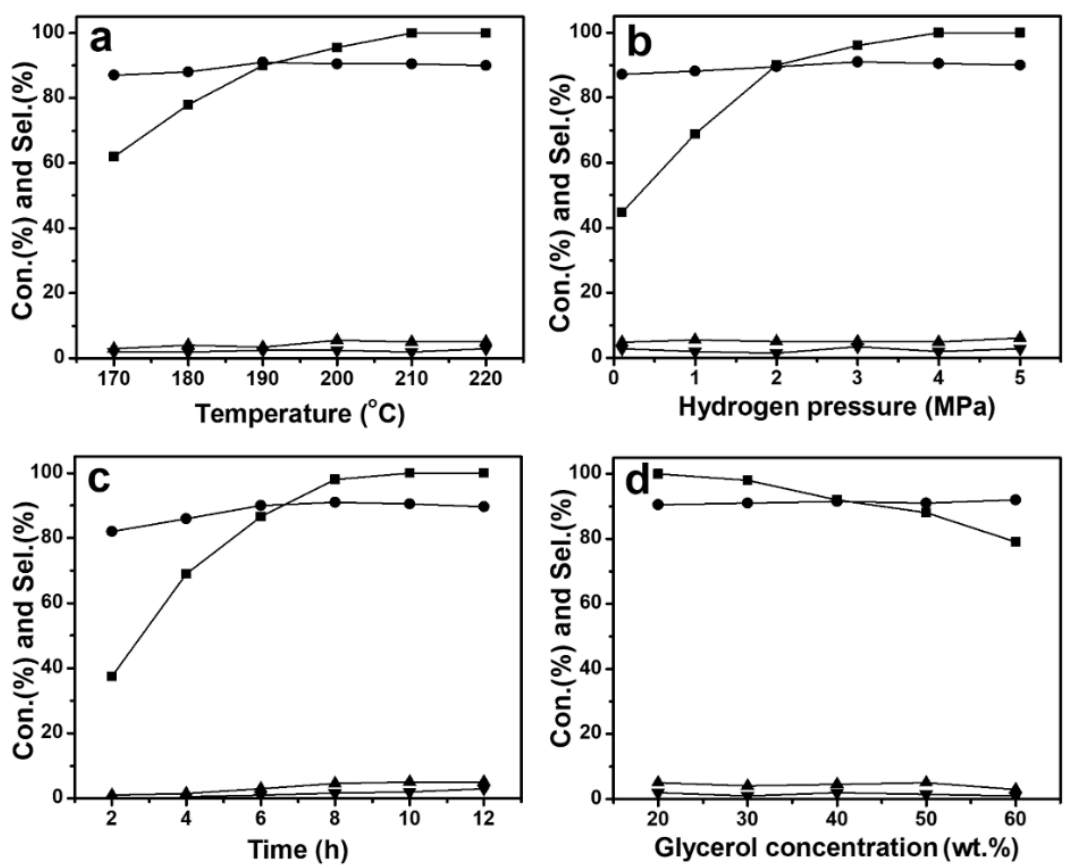

Figure S4. Influence of (a) temperature; (b) $\mathrm{H}_{2}$ pressure; (c) time evolution and (d) glycerol concentration on the catalytic performance of $\mathrm{Co}_{2}-\mathrm{Ca}_{4}-\mathrm{Al}_{3}$ catalyst in the hydrogenolysis of glycerol. (匹) glycerol conversion; (•) 1,2-PDO selectivity;

MeOH selectivity; ( $\Delta$ ) EG selectivity. $15.0 \mathrm{~mL} 20 \mathrm{wt} \%$ glycerol aqueous solution, 0.5 g catalyst, 4.0 $\mathrm{MPa} \mathrm{H} 2,10 \mathrm{~h}$. 


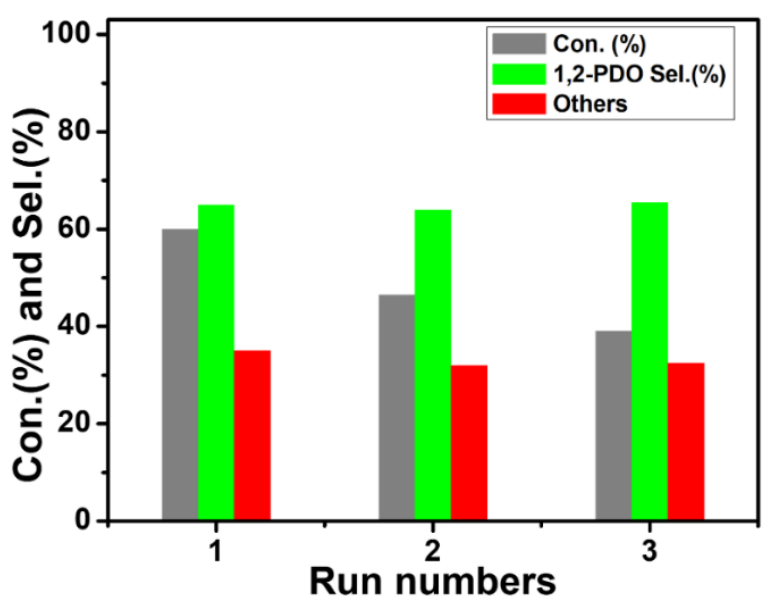

Figure S5. The recyclability of $\mathrm{Co}_{6}-\mathrm{Al}_{3}$ catalyst for selective hydrogenolysis of crude glycerol. Others: $\mathrm{EG}, \mathrm{MeOH}, 2-\mathrm{PO}, \mathrm{CO}_{2}, \mathrm{CO}, \mathrm{CH}_{4}$ and other unidentified products. Reaction conditions: $15.0 \mathrm{~mL}$ crude glycerol aqueous solution (50.2 wt \%), $0.5 \mathrm{~g}$ catalyst, $4.0 \mathrm{MPa} \mathrm{H}_{2}, 210^{\circ} \mathrm{C}, 10 \mathrm{~h}$. 


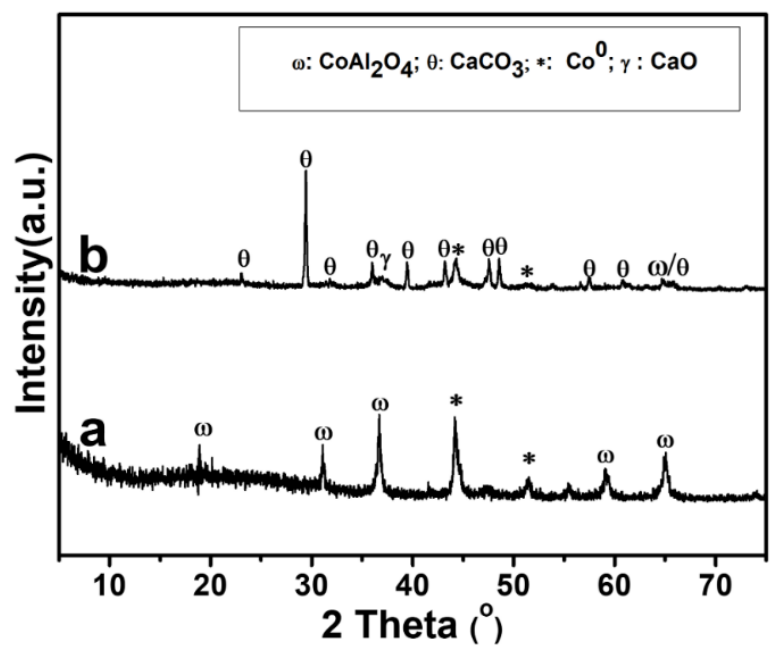

Figure S6. XRD patterns of the spent catalysts. (a) $\mathrm{Co}_{6}-\mathrm{Al}_{3} \_\mathrm{S}$; (b) $\mathrm{Co}_{2}-\mathrm{Ca}_{4}-\mathrm{Al}_{3} \_\mathrm{S}$. 


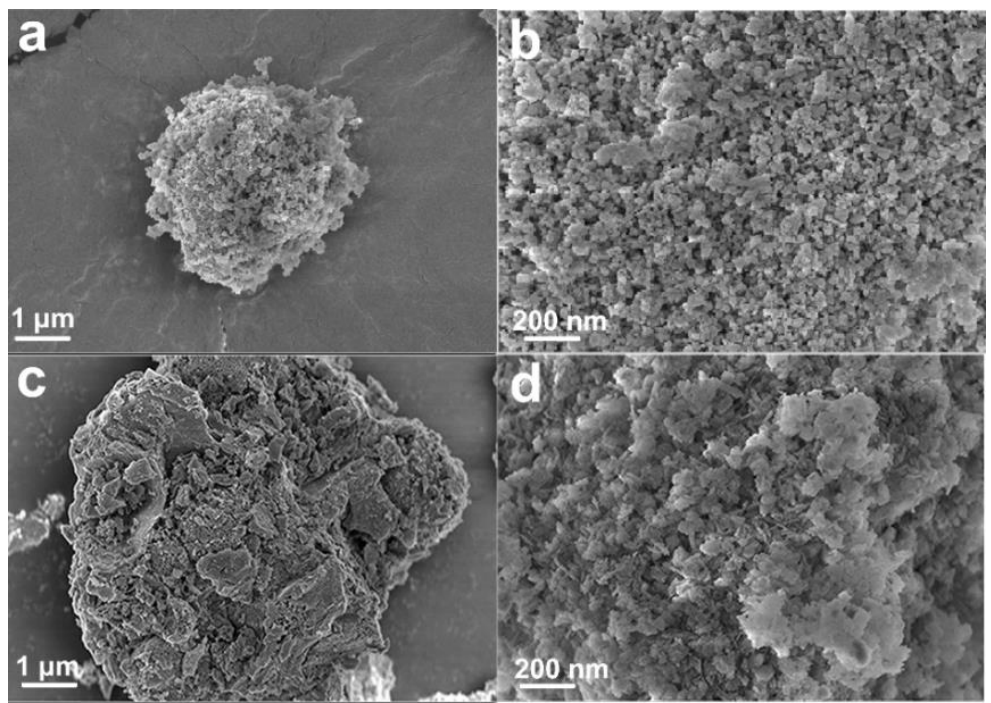

Figure S7. SEM images of the spent catalysts. (a, b) $\mathrm{Co}_{6}-\mathrm{Al}_{3} \_\mathrm{S}$; (c, d) $\mathrm{Co}_{2}-\mathrm{Ca}_{4}-\mathrm{Al}_{3} \_\mathrm{S}$. 


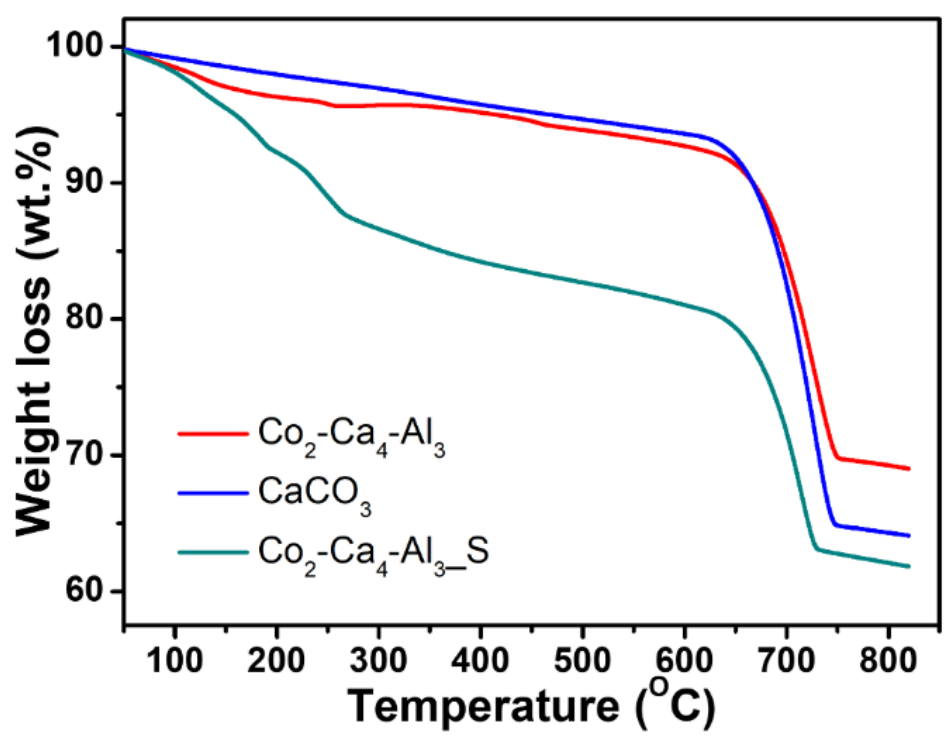

Figure S8. TGA curves of $\mathrm{Co}_{2}-\mathrm{Ca}_{4}-\mathrm{Al}_{3}, \mathrm{CaCO}_{3}$ and $\mathrm{Co}_{2}-\mathrm{Ca}_{4}-\mathrm{Al}_{3} \_\mathrm{S}$. 
Table S2. Comparison of the $\mathrm{Co}_{2}-\mathrm{Ca}_{4}-\mathrm{Al}_{3}$ catalyst with those reported catalytic systems in the selective hydrogenolysis of glycerol.

\begin{tabular}{|c|c|c|c|c|c|}
\hline Catalyst & Reaction conditions & $\begin{array}{c}\text { Yield of } \\
1,2-\mathrm{PDO} \\
(\%)\end{array}$ & $\begin{array}{c}\text { Run } \\
\text { numbers }\end{array}$ & $\begin{array}{l}\text { TOS } \\
(\mathrm{h})^{\mathrm{a}}\end{array}$ & Ref. \\
\hline $\mathrm{Cu} / \mathrm{ZrO}_{2}$ & $\begin{array}{l}4 \mathrm{wt} \% \text { glycerol aqueous } \\
\text { solution, } 200{ }^{\circ} \mathrm{C}, 10 \mathrm{~h}, 2.5 \\
\mathrm{MPa} \mathrm{H}_{2}\end{array}$ & 32.7 & 3 & n.d. & 1 \\
\hline $\mathrm{Cu}-\mathrm{Pd} / \mathrm{TiO}_{2}-\mathrm{Na}$ & $\begin{array}{l}20 \text { wt } \% \text { glycerol aqueous } \\
\text { solution, } 220{ }^{\circ} \mathrm{C}, 6 \mathrm{~h}, 0.7 \\
\mathrm{MPa} \mathrm{H}_{2}\end{array}$ & 55.3 & 4 & n.d. & 2 \\
\hline $\mathrm{ZnPd} / \mathrm{ZnO} @ \mathrm{Al}_{2} \mathrm{O}_{3}$ & $\begin{array}{l}20 \text { wt } \% \text { glycerol aqueous } \\
\text { solution, } 230{ }^{\circ} \mathrm{C}, 6 \mathrm{~h}, 3 \\
\mathrm{MPa} \mathrm{H}_{2}\end{array}$ & 74.2 & 5 & n.d. & 3 \\
\hline $8 \mathrm{Ce} / \mathrm{Cu}-\mathrm{Co}-\mathrm{Al}$ & $\begin{array}{l}20 \mathrm{wt} \% \text { glycerol ethanol } \\
\text { solution, } 230{ }^{\circ} \mathrm{C}, 3.5 \mathrm{MPa} \\
\mathrm{H}_{2}\end{array}$ & 84.6 & n.d. & 100 & 4 \\
\hline $\mathrm{PdZn} / \mathrm{ZnAl}{ }_{2} \mathrm{O}_{4}$ & $\begin{array}{l}10 \text { wt } \% \text { glycerol aqueous } \\
\text { solution, } 220{ }^{\circ} \mathrm{C}, 4 \mathrm{~h}, 5 \\
\mathrm{MPa} \mathrm{H}_{2}\end{array}$ & 31.5 & 10 & n.d. & 5 \\
\hline $\mathrm{Cu}_{0.1}-\mathrm{Mg}_{0.2} / \mathrm{SiO}_{2}$ & $\begin{array}{l}20 \text { wt } \% \text { glycerol aqueous } \\
\text { solution, } 210^{\circ} \mathrm{C}, 24 \mathrm{~h}, 4.5 \\
\mathrm{MPa} \mathrm{H}_{2}\end{array}$ & 82.8 & 5 & n.d. & 6 \\
\hline $8 \mathrm{Nb} / \mathrm{Pd}-\mathrm{Zr}-\mathrm{Al}$ & $\begin{array}{l}10 \text { wt } \% \text { glycerol aqueous } \\
\text { solution, } 200{ }^{\circ} \mathrm{C}, 8 \mathrm{~h}, 3.5 \\
\mathrm{MPa} \mathrm{H}_{2}\end{array}$ & 58.5 & 4 & n.d. & 7 \\
\hline $\mathrm{Ru} / \mathrm{Mg}(\mathrm{OH})_{2}(\mathrm{~S})$ & $\begin{array}{l}4.2 \text { wt } \% \text { glycerol aqueous } \\
\text { solution, } 210{ }^{\circ} \mathrm{C}, 2 \mathrm{~h}, 3 \\
\mathrm{MPa} \mathrm{H}_{2}\end{array}$ & 15.8 & 5 & n.d. & 8 \\
\hline PtIn-2 & $\begin{array}{l}10 \text { wt } \% \text { glycerol ethanol } \\
\text { solution, } 220^{\circ} \mathrm{C}, 12 \mathrm{~h}, 2 \\
\mathrm{MPa} \mathrm{H}_{2}\end{array}$ & 90.9 & 5 & n.d. & 9 \\
\hline $5 \mathrm{CuO} / \mathrm{Ga}_{2.3}-\mathrm{HT}$ & $\begin{array}{l}20 \text { wt } \% \text { glycerol aqueous } \\
\text { solution, } 220^{\circ} \mathrm{C}, 0.5 \mathrm{MPa} \\
\mathrm{H}_{2}\end{array}$ & 92.2 & n.d. & 23 & 10 \\
\hline $\mathrm{Co}_{2}-\mathrm{Ca}_{4}-\mathrm{Al}_{3}$ & $\begin{array}{l}20 \text { wt } \% \text { glycerol aqueous } \\
\text { solution, } 210{ }^{\circ} \mathrm{C}, 10 \mathrm{~h}, 4 \\
\mathrm{MPa} \mathrm{H}_{2}\end{array}$ & 90.5 & 6 & 280 & $\begin{array}{l}\text { This } \\
\text { work }\end{array}$ \\
\hline
\end{tabular}

${ }^{\mathrm{a}} \mathrm{TOS}$ : time on tream. 

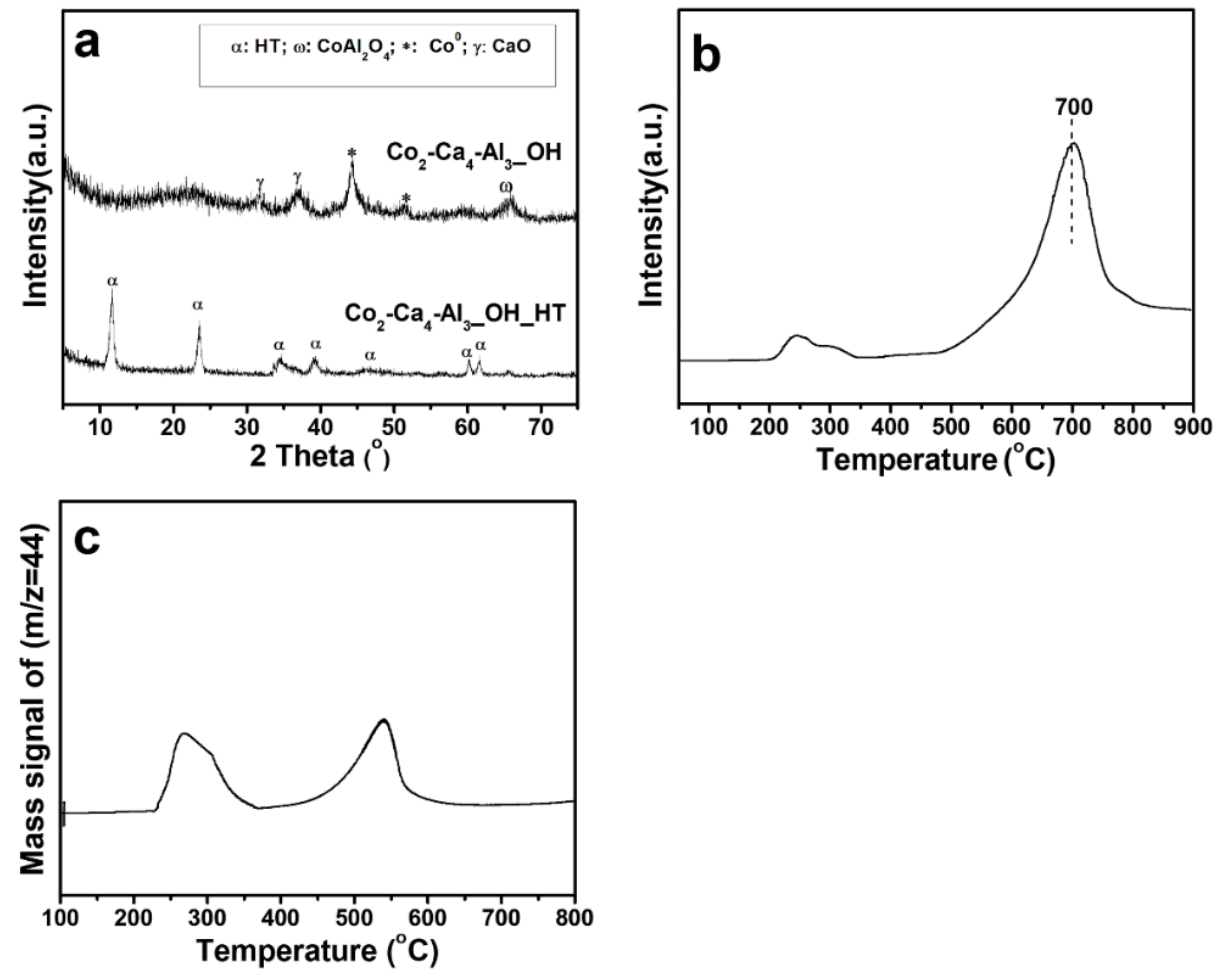

Figure S9. (a) XRD patterns of the $\mathrm{Co}_{2}-\mathrm{Ca}_{4}-\mathrm{Al}_{3} \_\mathrm{OH} \_\mathrm{HT}$ and $\mathrm{Co}_{2}-\mathrm{Ca}_{4}-\mathrm{Al}_{3} \_\mathrm{OH}$. (b) $\mathrm{H}_{2}-$ TPR profiles of the $\mathrm{Co}_{2}-\mathrm{Ca}_{4}-\mathrm{Al}_{3} \mathrm{OH}_{-} \mathrm{HT}$. (c) $\mathrm{CO}_{2}-\mathrm{TPD}$ profiles of $\mathrm{Co}_{2}-\mathrm{Ca}_{4}-\mathrm{Al}_{3} \_\mathrm{OH}$ catalyst. 
Table S3. The hydrogenolysis of glycerol on various catalysts by controlling the reaction conditions. ${ }^{\mathrm{a}}$

\begin{tabular}{|c|c|c|c|c|c|c|c|}
\hline \multirow{2}{*}{ Entry } & \multirow{2}{*}{ Catalysts } & \multirow{2}{*}{ Con. (\%) } & \multicolumn{5}{|c|}{ Sel. $(\%)$} \\
\hline & & & 1,2-PDO & EG & DHA & LA & Others ${ }^{\mathrm{e}}$ \\
\hline 1 & $\mathrm{Co}_{2}-\mathrm{Ca}_{4}-\mathrm{Al}_{3}$ & 73.0 & 91.0 & 2.7 & - & 2.3 & 4.0 \\
\hline 2 & $\mathrm{Co}_{2}-\mathrm{Ca}_{4}-\mathrm{Al}_{3} \_\mathrm{OH}$ & 76.5 & 74.4 & 3.5 & - & 13.5 & 8.6 \\
\hline 3 & $\mathrm{Co}_{2}-\mathrm{Ca}_{4}-\mathrm{Al}_{3} \mathrm{Ox}_{\mathrm{x}}$ & 6.0 & 5.5 & 2.3 & - & 77.0 & 15.2 \\
\hline 4 & $\mathrm{Co}_{2}-\mathrm{Ca}_{4}-\mathrm{Al}_{3} \mathrm{Ox}^{\mathrm{b}}$ & 3.5 & 4.0 & 1.5 & - & 74.5 & 20.0 \\
\hline 5 & $\mathrm{Co}_{2}-\mathrm{Ca}_{4}-\mathrm{Al}_{3}{ }^{\mathrm{b}}$ & 23.0 & 47.3 & 12.5 & - & 26.5 & 13.7 \\
\hline 6 & $\mathrm{Co}_{2}-\mathrm{Ca}_{4}-\mathrm{Al}_{3}{ }^{\mathrm{c}}$ & 13.5 & - & - & 69.0 & 10.5 & 20.5 \\
\hline 7 & $\mathrm{Co}_{2}-\mathrm{Ca}_{4}-\mathrm{Al}_{3}{ }^{\mathrm{d}}$ & 100 & 58.0 & 3.5 & - & 2.5 & 36.0 \\
\hline \multicolumn{8}{|c|}{ a Reaction conditions: $15.0 \mathrm{~mL} 20 \mathrm{wt} \%$ glycerol aqueous solution, $0.5 \mathrm{~g}$ catalyst, $4.0 \mathrm{MPa}$} \\
\hline \multirow{2}{*}{\multicolumn{8}{|c|}{$\begin{array}{l}\mathrm{H}_{2}, 210^{\circ} \mathrm{C}, 5 \mathrm{~h} \text { unless indicated otherwise. }{ }^{\mathrm{b}} \mathrm{The} \text { reaction was carried out under } \mathrm{N}_{2} \\
\text { atmosphere }(1.0 \mathrm{MPa}){ }^{\mathrm{c}} \text { The reaction was carried out under } \mathrm{N}_{2} \text { atmosphere (1.0 MPa), } \\
80^{\circ} \mathrm{C}, 24 \mathrm{~h} .{ }^{\mathrm{d}} 20 \mathrm{wt} \% \text { of DHA aqueous solution was used as substrate. }{ }^{\mathrm{e}} \text { Others: } \mathrm{CO}_{2}, \mathrm{CO} \text {, }\end{array}$}} \\
\hline & & & & & & & \\
\hline \multicolumn{8}{|c|}{$\mathrm{CH}_{4}, \mathrm{MeOH}, 2-\mathrm{PO}$ and other unidentified products. 1,2-PO: 1,2-propanediol; EG: ethylene } \\
\hline glycol; & DHA: Dihydroxyace & tone; $2-\mathrm{PO}$ & 2-propanol. & & & & \\
\hline
\end{tabular}




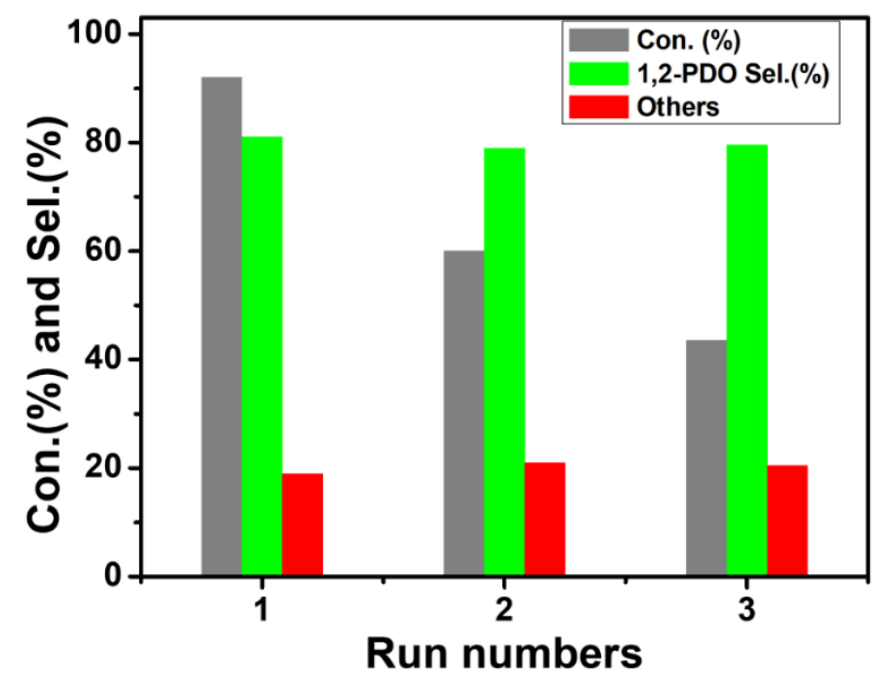

Figure S10. The recyclability of $\mathrm{Co}_{2}-\mathrm{Ca}_{4}-\mathrm{Al}_{3} \_\mathrm{OH}$ catalyst for selective hydrogenolysis of crude glycerol. Others: $\mathrm{EG}, \mathrm{MeOH}, 2-\mathrm{PO}, \mathrm{LA}, \mathrm{CO}_{2}, \mathrm{CO}, \mathrm{CH}_{4}$ and other unidentified products. Reaction conditions: $15.0 \mathrm{~mL}$ crude glycerol aqueous solution (50.2 wt \%), 0.5 g catalyst, $4.0 \mathrm{MPa} \mathrm{H}, 210^{\circ} \mathrm{C}, 10 \mathrm{~h}$. 

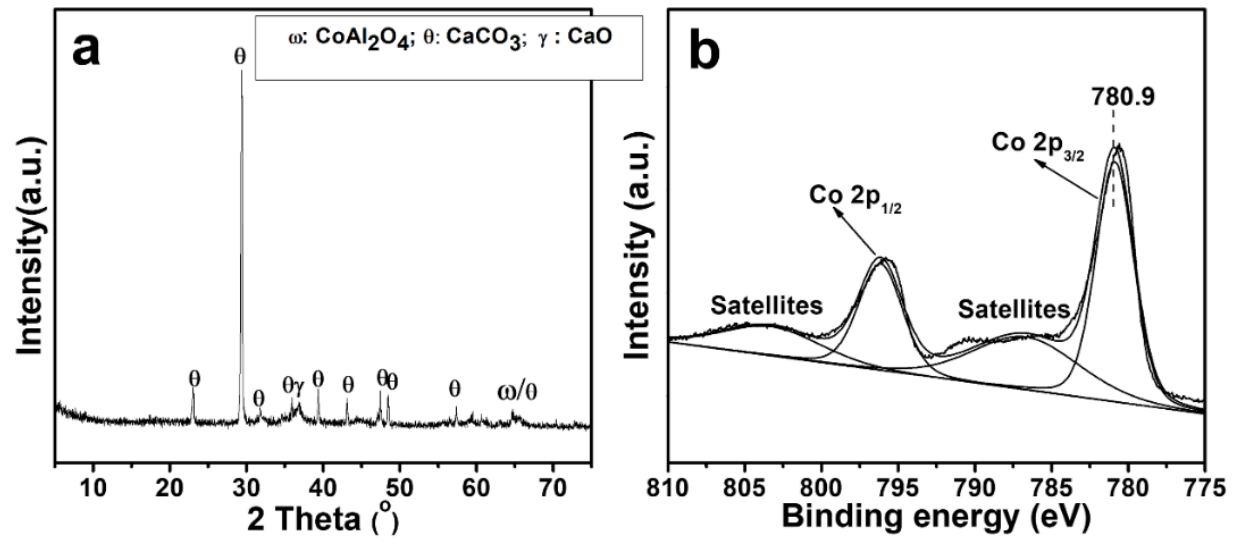

Figure S11. (a) XRD patterns of the $\mathrm{Co}_{2}-\mathrm{Ca}_{4}-\mathrm{Al}_{3}$ Ox catalyst; (b) Co $2 \mathrm{p}$ XPS spectrum of the $\mathrm{Co}_{2}-\mathrm{Ca}_{4}-\mathrm{Al}_{3} \_\mathrm{Ox}$ catalyst.

\section{References}

(1) Gabrysch, T.; Peng, B.; Bunea, S.; Dyker, G.; Muhler, M. The Role of metallic copper in the selective hydrodeoxygenation of glycerol to 1,2-propanediol over $\mathrm{Cu} / \mathrm{ZrO}_{2}$. ChemCatChem 2018, 10, 1344-1350, DOI: 10.1002/cctc.201701748.

(2) Ardilaa, A.; Sánchez-Castilloc, M.; Zepedad, T.; Villae, A.; Fuentes, G. Glycerol hydrodeoxygenation to 1,2-propanediol catalyzed by $\mathrm{CuPd} / \mathrm{TiO}_{2}-\mathrm{Na}$. Appl. Catal. B: Environ. 2017, 219, 658-671, DOI: 10.1016/j.apcatb.2017.08.006.

(3) Li, X.; Zhang, B.; Wu, Q.; Zhang, C.; Yu, Y.; Li, Y.; Lin, W.; Cheng, H.; Zhao, F. A facile strategy for confining $\mathrm{ZnPd}$ nanoparticles into a $\mathrm{ZnO} @ \mathrm{Al}_{2} \mathrm{O}_{3}$ support: A stable catalyst for glycerol hydrogenolysis. J. Catal. 2016, 337, 284-292, DOI: 10.1016/j.jcat.2016.01.024.

(4) Cai, F.; Xiao. G. Promoting effect of $\mathrm{Ce}$ on a $\mathrm{Cu}-\mathrm{Co}-\mathrm{Al}$ catalyst for the hydrogenolysis of glycerol to 1,2-propanediol. Catal. Sci. Technol. 2016, 6, 5656-5667, DOI: $10.1039 /$ c6cy00116e.

(5) Zhang, X.; Liu, C.; Ke, C.; Liu, L.; Hao, X.; Wu, Y.; Wan, S.; Wang, S.; Wang Y. Hydrothermally stable $\mathrm{ZnAl}_{2} \mathrm{O}_{4}$ nanocrystals with controlled surface structures for the design of long-lasting and highly active/selective PdZn catalysts. Green Chem. 2019, 21, 6574-6578, DOI: 10.1039/c9gc02483b.

(6) Kumar, P.; Shah, A.; Lee, J.; Park, Y.; Štangar, U.; Selective hydrogenolysis of 
glycerol over bifunctional copper-magnesium-supported catalysts for propanediol synthesis. Ind. Eng. Chem. Res. 2020, 59, 6506-6516, DOI: 10.1021/acs.iecr.9b06978. (7) Cai, F.; Jin, F.; Hao, J.; Xiao, G. Selective hydrogenolysis of glycerol to 1,2propanediol on Nb-modified Pd-Zr-Al catalysts. Catal. Commun. 2019, 131, 105801, DOI: $10.1016 /$ j.catcom.2019.105801.

(8) Liu, J.; Ruan, L.; Liao, J.; Pei, An.; Yang, K.; Zhu, L.; Chen, B. Magnesium hydroxide-supported ruthenium as an efficient and stable catalyst for glycerol-selective hydrogenolysis without addition of base and acid additives. New J. Chem. 2020, 44, 16054-16061, DOI: 10.1039/d0nj03157g.

(9) Zhang, X.; Cui, G.; Wei, M. PtIn alloy catalysts toward selective hydrogenolysis of glycerol to 1,2-propanediol. Ind. Eng. Chem. Res. 2020, 59, 12999-13006, DOI: 10.1021/acs.iecr.0c02299.

(10) Mittaa, H.; Devunurib, N.; Sunkaric, J.; Mutyalad, S.; Ballae, P.; Perupogua, V. A highly active dispersed copper oxide phase on calcined $\mathrm{Mg}_{9} \mathrm{Al}_{2.7}-\mathrm{Ga}_{2.3} \mathrm{O}_{2}$ catalysts in glycerol hydrogenolysis. Catal. Today 2020, DOI: 10.1016/j.cattod.2020.02.032. 